\title{
New long-term mass-balance series for the Swiss Alps
}

\author{
Matthias HUSS, ${ }^{1,2}$ Laurie DHULST, ${ }^{1}$ Andreas BAUDER ${ }^{1}$ \\ ${ }^{1}$ Laboratory of Hydraulics, Hydrology and Glaciology (VAW), ETH Zürich, Zürich, Switzerland \\ ${ }^{2}$ Department of Geosciences, University of Fribourg, Fribourg, Switzerland \\ Correspondence: Matthias Huss <huss@vaw.baug.ethz.ch>
}

\begin{abstract}
In this study we present 19 new or re-analysed series of glacier-wide seasonal mass balance for the Swiss Alps based on direct measurements. The records partly start around 1920 and continue until today. Previously unpublished and unevaluated observations of point winter and annual balance are compiled from various sources and archives. These highly valuable datasets have not yet been consistently evaluated and were thus unavailable to the scientific community. Using distributed modelling for spatial interpolation and extrapolation and homogenization of the point measurements, we infer continuous series of area-averaged mass balance. The results are validated against independent decadal ice volume changes from photogrammetric surveys. Six of the new seasonal series cover 60 years and more and add a substantial amount of information on the variations of regional glacier mass change. This will strengthen the worldwide collection of glacier monitoring data, especially for the data-sparse period before the 1980s. We compare our results to existing long-term series and present an updated assessment of mass-balance variability and glacier sensitivity throughout the European Alps.
\end{abstract}

KEYWORDS: climate change, glacier mass balance

\section{INTRODUCTION}

The surface mass balance of mountain glaciers is a valuable indicator of climate change (e.g. Oerlemans and Fortuin, 1992; Kaser and others, 2006). Globally coordinated monitoring efforts have contributed to a comprehensive set of time series, documenting variations in glacier-wide mass balance for >100 glaciers (Zemp and others, 2009; WGMS, 2012). However, only a few series are longer than 20 years and even fewer start before the 1980s. In comparison with other mountain ranges worldwide, glaciers in the European Alps are characterized by the highest density of massbalance records (Braithwaite, 2002). However, given the strong differences in the response of individual glaciers, as well as the poor representativeness of some series for their respective region (Kuhn and others, 1985; Huss, 2012), more direct information on mass-balance variability is required even in the Alps. Furthermore, only a fraction of the records yield seasonal mass budget components (Zemp and others, 2009), although these are of eminent importance for understanding glacier response to shifts in climatic forcing (Dyurgerov and Meier, 1999; Ohmura and others, 2007; Braithwaite, 2009).

The wealth of glacier mass-balance data over the past few decades - both in terms of spatial and temporal coverage and resolution (seasonal/annual) - can be increased by compiling and/or re-analysing scattered measurements that have not yet been consistently evaluated. Such series probably exist for other mountain ranges around the globe, but are likely to be most frequent in the Swiss Alps. In fact, extensive mass-balance observations with seasonal resolution, sometimes stretching over 100 years, have been performed on more than a dozen glaciers and in some cases monitoring has continued until the present. Raw data have been stored in local archives in different formats; sometimes only as handwritten reports never mentioned in any official publication. No (or only incomplete) evaluations of glacierwide mass balance have been performed so far. Compiling the point mass-balance data from their original sources, re-analysing them following a consistent procedure and making them available to the glaciological community via international data centres is important to foster scientific studies and to advance our understanding of glacier response to climate forcing. Furthermore, in the long run, inaccessible data face the fate of falling into oblivion and need to be 'rescued' whenever possible.

Repeated uncertainty assessment and re-analysis of massbalance series is an important concept of modern glacier monitoring (Haeberli and others, 2007). It ensures that published mass balances are accurate, and thus are useful indicators of glacier change. Several studies have recently addressed the homogenization of long-term series (e.g. Thibert and others, 2008; Cogley, 2009; Huss and others, 2009a; Zemp and others, 2010; Fischer, 2011; Carturan and others, 2013). Such efforts are based on a detailed reassessment of the raw point measurements, the methods of interpolation and extrapolation, and validation against independent ice volume changes, obtained from the comparison of digital elevation models (DEMs). Due to a lack of geodetic surveys or incomplete records in the original data, however, no re-analysis has yet been performed for the majority of mass-balance series worldwide.

For the Swiss Alps, two mass-balance series based on the direct glaciological methods covering five decades are available (Glaciological reports, 1881-2014; WGMS, 2012). Continuous long-term point measurements at a considerable number of additional glaciers have also been performed, often with a seasonal resolution. In some cases, the spatial point density of these monitoring programmes was not judged to be sufficient for calculating glacier-wide balance. In other cases, the measurements were only acquired as point balance series, or in connection to surveys of glacier flow speed. Point mass-balance measurements directly reveal the effect of climatic forcing, independent of dynamic glacier response (Vincent and others, 2004; Huss and others, 2009b), and are highly valuable for calibrating and validating glacier models (e.g. Radić and Hock, 2014). 


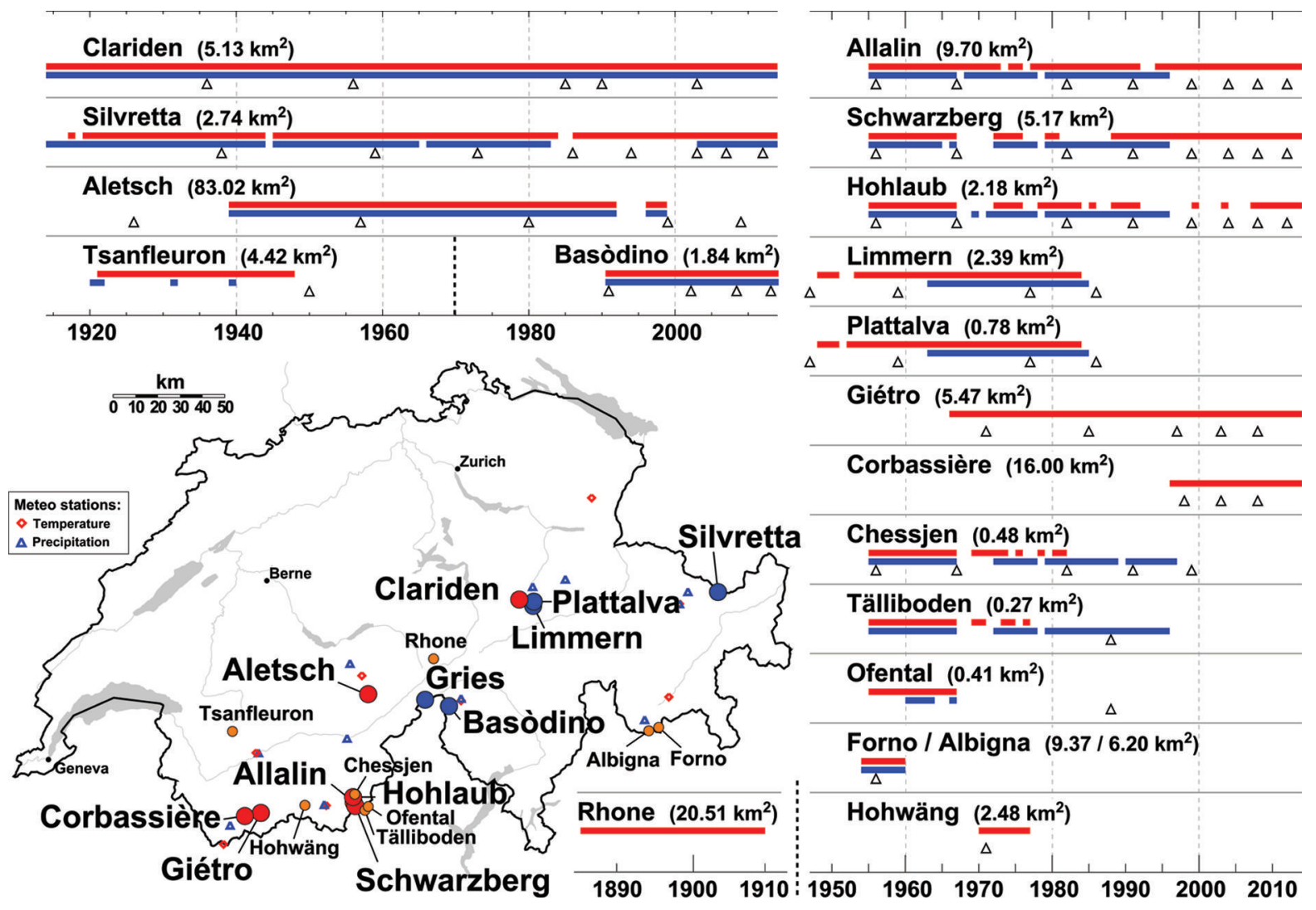

Fig. 1. Data coverage and location of the study sites in Switzerland. Previous long-term monitoring series are marked with blue circles; longterm series evaluated in this study are displayed with red circles. Small orange circles indicate shorter or less homogeneous new series. The locations of meteorological stations used for mass-balance calculations are depicted (diamonds: temperature; triangles: precipitation). The availability of point mass-balance data for the annual period (red bars) and the winter period (blue bars) is visualized on a time axis. Years with DEMs are shown by triangles.

Nevertheless, time series of glacier-wide mass balance are indispensable for many glaciological applications (e.g. assessment of water storage changes or comparing rates of mass change between different glaciers and mountain ranges (Harrison and others, 2005; Zemp and others, 2009; Gardner and others, 2013)).

In this study we present 19 new or re-analysed series of glacier-wide seasonal mass balance for the Swiss Alps based on in situ observations. We compile previously unpublished and unevaluated measurements of winter accumulation and annual balance and generate a comprehensive collection of point data since the late 19th century. Based on a technique employing distributed modelling for spatially interpolating and extrapolating the measurements over the glacier surface, we compute homogeneous mass-balance series. We validate our results against independent ice volume changes from photogrammetric surveys acquired in time intervals of a few years to several decades. The combination of in situ measurements with a high temporal resolution and long-term mass change from the geodetic method allows us to detect and reduce the observational bias, and hence to infer area-averaged mass balance, even with relatively few annual point observations.

Two of the series evaluated in this paper cover a continuous period of $\sim 100$ years. They thus represent the longest records of glacier-wide mass balance worldwide, and provide the first direct information on seasonal/annual glacier mass change before 1946. Four additional series span six decades. Moreover, a seasonal resolution over multiple decades is available for most glaciers, which is exceptional, even at the global scale. Our dataset adds substantial knowledge about glacier change in the Alps. This is expected to considerably strengthen the collection of monitoring data globally, especially before the 1980s, and to offer an extended basis for studying the relationships between glaciers and the climate. We analyse the regional differences in mass-balance variability throughout the 20th century and compare our results to existing long-term series in the Alps.

\section{DATA AND STUDY SITES}

The measurement of glacier surface mass balance using the glaciological method has a long tradition in Switzerland. As early as 1884 an extensive stake network for monitoring the spatial variation of ice ablation was installed on Rhonegletscher (Mercanton, 1916). Around 1920, seasonal point observations in the accumulation area were initiated at five glaciers in the Swiss Alps (Clariden, Silvretta, Aletsch, Tsanfleuron, Trient; Glaciological reports, 1881-2014; Firnberichte, 1914-78; Aellen, 1996), but no glacier-wide mass-balance values were calculated from these data. Only two long-term series (Silvretta, Gries) have been maintained as regular monitoring programmes from the 1960s until today, with data being available to international data archives (WGMS, 2012). Mass-balance observations on Limmern- and Plattalvafirn were discontinued in 1984 after $\sim 40$ years. Since 1991, measurements at Ghiacciaio del Basòdino have delivered seasonal balances, and more recently several additional glaciers have been included in the framework of national glacier monitoring (e.g. Findelen, 
Table 1. Study site overview for all investigated glaciers with previously unevaluated or re-analysed series of glacier-wide mass balance. Glaciers are ordered according to time series length, $\Delta t$. Area corresponds to the end of the observation period. The number of DEMs, $n_{\mathrm{DEM}}$, for calculating geodetic mass change is given. $\overline{n_{\mathrm{a}}}$ and $\overline{n_{\mathrm{w}}}$ refer to the average number of point observations of annual and winter balance per year, with the maximum number of measurements within one year given in parentheses. $z_{\text {stake }}$ is the elevation range covered by the point measurements. The percentage of data gaps for annual balance and the time resolution of the evaluated series are given. Parentheses indicate that seasonal data are not available for the entire period. The type of the series is classified ( $\mathrm{n}$ : new/unpublished; p: point mass balances recently published, new evaluation of glacier-wide balance; e: extension of existing series; r: re-analysis of existing series)

\begin{tabular}{|c|c|c|c|c|c|c|c|c|c|c|}
\hline Glacier & Period & $\begin{array}{c}\Delta t \\
\text { years }\end{array}$ & $\begin{array}{l}\text { Area } \\
\mathrm{km}^{2}\end{array}$ & $\begin{array}{c}\text { Elev. range } \\
\text { ma.s.l. }\end{array}$ & $n_{\text {DEM }}$ & $\overline{n_{a}}$ & $\overline{n_{\mathrm{w}}}$ & $\begin{array}{c}Z_{\text {stake }} \\
\text { m a.s.l. }\end{array}$ & $\begin{array}{c}\text { Gaps } \\
\%\end{array}$ & Resolution \\
\hline
\end{tabular}

\begin{tabular}{|c|c|c|c|c|c|c|c|c|c|c|c|}
\hline Clariden & 1914-2014 & 100 & 5.13 & 2440-3207 & 5 & $2(2)$ & $2(2)$ & 2680-2892 & 0 & seasonal & $\mathrm{p}$ \\
\hline Silvretta & 1918-2014 & 96 & 2.74 & $2470-3075$ & 8 & $13(43)$ & $2(550)$ & 2477-2993 & 4 & seasonal & $e, p$ \\
\hline Aletsch & 1939-99 & 60 & 83.02 & 1560-4085 & 5 & $16(62)$ & $4(6)$ & $1660-3510$ & 7 & seasonal & $n, p, r$ \\
\hline Allalin & 1955-2014 & 59 & 9.70 & 2656-4180 & 8 & $6(10)$ & $2(9)$ & 2819-3385 & 7 & (seasonal) & $\mathrm{n}$ \\
\hline Schwarzberg & 1955-2014 & 59 & 5.17 & $2669-3566$ & 8 & $2(6)$ & $1(6)$ & $2726-3231$ & 25 & (seasonal) & $\mathrm{n}$ \\
\hline Hohlaub & 1955-2014 & 59 & 2.18 & $2843-4030$ & 8 & $1(3)$ & $1(3)$ & 2936-3186 & 39 & (seasonal) & $\mathrm{n}$ \\
\hline Giétro & 1966-2014 & 48 & 5.47 & 2619-3820 & 5 & $9(10)$ & 0 & 2619-3306 & 0 & annual & $n$ \\
\hline Limmern & 1948-84 & 36 & 2.39 & $2213-3360$ & 4 & $27(55)$ & $2(3)$ & 2238-2947 & 5 & (seasonal) & $r$ \\
\hline Plattalva & $1948-84$ & 36 & 0.78 & 2554-2995 & 4 & $9(17)$ & $2(2)$ & $2577-2825$ & 3 & (seasonal) & $r$ \\
\hline Tsanfleuron & $1921-48$ & 27 & 4.42 & 2490-2980 & 1 & $1(1)$ & $1(1)$ & $2850-2850$ & 7 & annual & $n$ \\
\hline Chessjen & 1955-82 & 27 & 0.48 & 2854-3225 & 3 & $2(2)$ & $2(2)$ & 2885-2992 & 22 & seasonal & $\mathrm{n}$ \\
\hline Rhone & 1884-1910 & 26 & 20.51 & $1775-3620$ & 1 & $8(16)$ & 0 & 1804-2990 & 0 & annual & $r$ \\
\hline Basòdino & 1991-2014 & 23 & 1.84 & 2444-3181 & 4 & $10(14)$ & $10(12)$ & 2610-3052 & 0 & seasonal & $r$ \\
\hline Tälliboden & 1955-77 & 22 & 0.27 & 2631-2955 & 1 & $1(2)$ & $2(2)$ & $2672-2725$ & 23 & seasonal & $\mathrm{n}$ \\
\hline Corbassière & 1996-2014 & 18 & 16.00 & $2217-4310$ & 3 & $7(7)$ & 0 & $2467-2660$ & 0 & annual & $\mathrm{n}$ \\
\hline Ofental & 1955-67 & 12 & 0.41 & $2651-3023$ & 1 & $3(3)$ & $1(3)$ & 2659-2773 & 0 & seasonal & $\mathrm{n}$ \\
\hline Hohwäng & 1970-77 & 7 & 2.48 & 2830-3685 & 1 & $14(18)$ & 0 & $2900-3480$ & 0 & annual & $\mathrm{n}$ \\
\hline Forno & 1954-60 & 6 & 9.37 & 2125-3366 & 1 & $11(13)$ & $12(13)$ & $2176-3101$ & 0 & seasonal & $\mathrm{n}$ \\
\hline Albigna & 1954-60 & 6 & 6.20 & 2159-3314 & 1 & $9(11)$ & $12(14)$ & 2168-3106 & 0 & seasonal & $\mathrm{n}$ \\
\hline
\end{tabular}

Rhone, Pizol; Glaciological reports, 1881-2014). Figure 1 shows the location of all available series.

Mass-balance observations for the present study were compiled from various sources (mostly in the frame of previous projects). A considerable number of data were digitized from old published series on Swiss glacier monitoring (Firnberichte, 1914-78; Glaciological reports, 18812014). Other data were directly accessed via original handwritten reports by the observers. Several monitoring programmes were initiated in collaboration with hydropower companies, and data were obtained via internal reports by the Laboratory of Hydraulics, Hydrology and Glaciology, ETH Zürich. We collected the start and end dates of the seasonal/annual observation period, the coordinates, and ice ablation/snow accumulation for every measurement site. Exact dates of the surveys are lacking for $\sim 20 \%$ of the data. Direct information on snow/firn density was available in some cases, and was estimated otherwise.

Geodetic mass changes over sub-decadal to semicentennial periods are available for most of the investigated glaciers (Bauder and others, 2007, updated). Up to eight DEMs based on high-resolution aerial photogrammetry have been acquired over the period with direct observations providing (1) a time series of ice volume variations, permitting the repeated validation of glaciological mass balances, and (2) up-to-date information on ice surface topography and extent. All aerial photographs were coregistered to the same tie points and their quality was individually assessed. The agreement of consecutive DEMs was inspected over ice-free terrain. A few DEMs before 1950 are based on topographic maps (Silvretta, Clariden). Figure 1 and Table 1 summarize data availability for all sites.

Seasonal measurements at two stakes on Claridenfirn (Fig. 2a) have been carried out since 1914 without interruption. Müller and Kappenberger (1991) and Huss and Bauder (2009) presented re-evaluations of the point data and underlined their exceptional quality. Calculation of glacier-wide mass balance is challenging, due to occasional ice break-off over a rock cliff at the glacier front, i.e. an ablation process that is unrelated to surface melt.

Before the initiation of the established monitoring programme at Silvrettagletscher in 1959, seasonal massbalance observations had been maintained at one site at the equilibrium-line altitude (ELA) and at one site in the accumulation area since 1918 (Huss and Bauder, 2009). These data were used to extend the series to a 96 year continuous mass-balance record (Table 1).

Grosser Aletschgletscher is the largest glacier in the European Alps (Fig. 2c). Between the 1940s and the 1980s, extensive seasonal mass-balance observations with up to 60 point measurements per year were performed. Although the annual mass budget was assessed using the hydrological method (Aellen and Funk, 1990), no evaluation of glacierwide seasonal balance based on the in situ mass-balance observations and in agreement with the observed long-term volume change is available. Seasonal surveys at one stake in the accumulation area have been carried out from 1919 until today (Glaciological reports, 1881-2014). Due to the large surface area of Aletsch these data do not, however, allow calculation of the glacier-wide mass balance and we limit ourselves to the period 1939-99, when there are sufficient measurements.

In the catchment of the Mattmark reservoir, located in a relatively dry region on the southern Alpine crest, considerable efforts to monitor glacier mass balance have been undertaken. In 1955, seasonal observations on six glaciers were initiated. The measurements on Allalin-, Schwarzbergand Hohlaubgletscher have continued until the present 

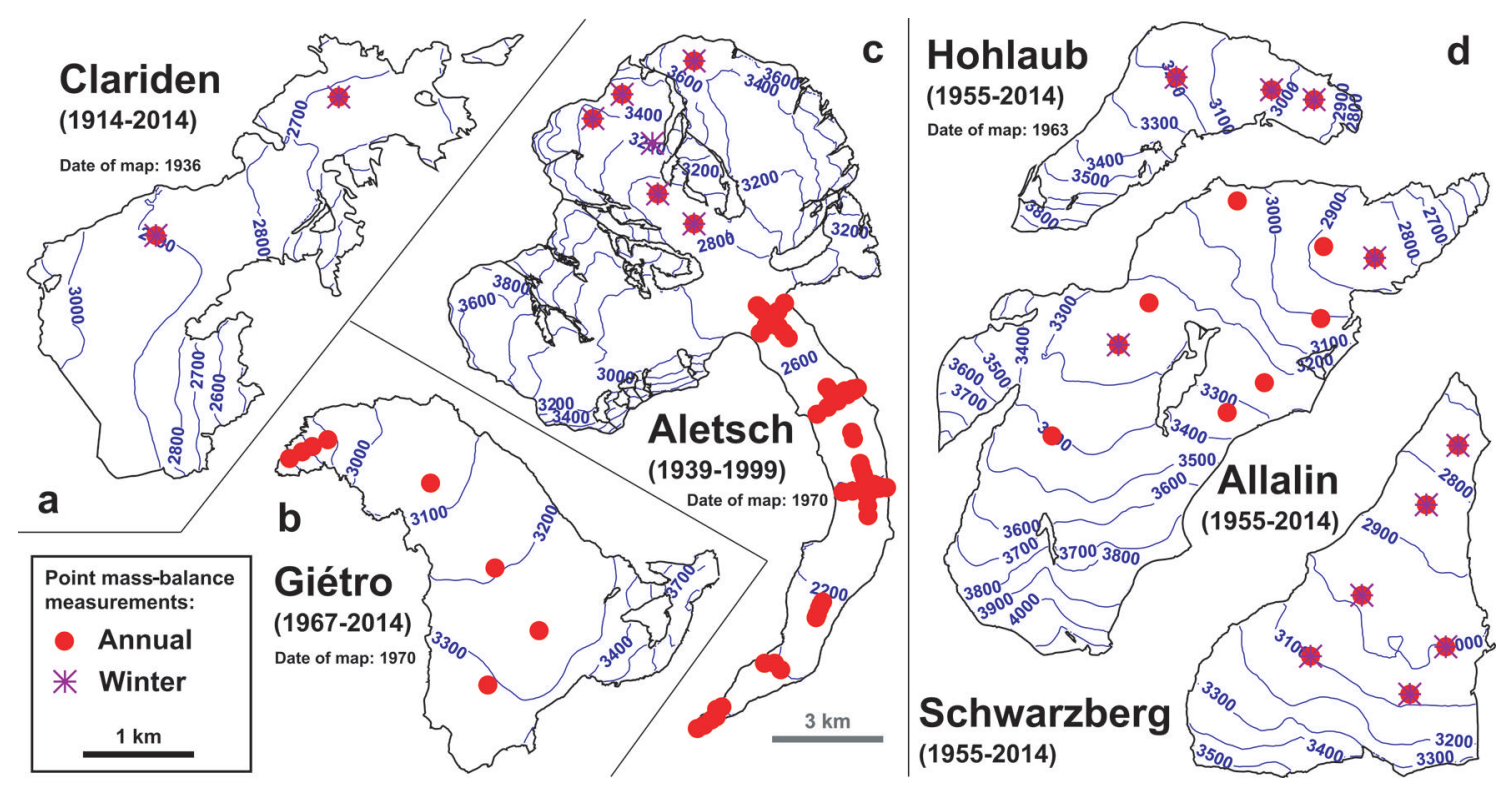

Fig. 2. Overview maps of the most important study sites: (a) Clariden, (b) Giétro, (c) Aletsch and (d) Hohlaub, Allalin and Schwarzberg. The location of point measurements of annual and winter balance for a selected year is shown by symbols. The date of the glacier outline and surface topography is specified. Note that the scale of (c) is reduced by a factor of three. For investigated glaciers not shown in this figure the reader is referred to previous publications (e.g. Glaciological reports, 1881-2014; Huss and others, 2009a).

(Fig. 2d). Observations of winter accumulation were carried out until 1996. For each glacier, eight DEMs are available throughout the study period. Although some data gaps are present, these 60 year series provide highly valuable information for a region of the European Alps for which no long-term mass-balance records have yet been published. Seasonal series with a coverage of several decades also exist for Chessjen-, Tälliboden- and Ofentalgletscher located in the same area (Table 1). These three small cirque glaciers have now almost completely vanished.

A high-quality mass-balance programme has been maintained on Glacier du Giétro in the western Swiss Alps for $\sim 50$ years. Annual balance is determined at nine stakes (Fig. 2b) related to the monitoring of surface flow speed (Glaciological reports, 1881-2014). No surveys of winter accumulation are available. Since 1996, similar observations exist for Glacier de Corbassière, a nearby valley glacier (Fig. 1). The measurements at seven stakes are restricted to the ablation area. For both glaciers areaaveraged mass balance has, as yet, been neither evaluated nor published.

Between 1948 and 1984, Limmern- and Plattalvafirn, two rather small neighbouring glaciers in central Switzerland (Fig. 1), were subject to extensive mass-balance studies, with $>50$ stakes in some years. Glacier-wide mass balance was evaluated and published (Glaciological reports, 18812014; WGMS, 2012). Comparison with observed decadal ice volume changes, however, indicates a need for reanalysis. Furthermore, in situ surveys of winter accumulation (Hock and others, 1993) were included here, adding the seasonal component to these records. Similarly, we also re-analysed the existing series for Ghiacciaio del Basòdino in this study. Four geodetic surveys between 1991 and 2013 allow us to validate glaciological mass balances calculated from the comprehensive stake network (Table 1).

Within this study, data for additional glaciers with shorter or less-homogenous series were compiled and seasonal/ annual glacier-wide mass balances were evaluated. We do not present these results in as much detail as the above series because no repeated geodetic surveys are available for validation and, hence, results are more uncertain. Annual mass balances for Rhonegletscher based on Mercanton (1916) were re-evaluated for the period 1884-1910. Continuous measurements at one stake on Glacier de Tsanfleuron (Fig. 1; Glaciological reports, 1881-2014) from 1921-48 were analysed. A short but complete series exists for Hohwänggletscher in the 1970s (Schnyder, 2009). Highquality monitoring with seasonal resolution was carried out on Vadret dal Forno and Albigna in southeastern Switzerland in the late 1950s (Table 1).

We also use $\sim 20$ additional long-term series of annual balance based on the direct glaciological method for other glaciers in the European Alps for comparison with results of this study. Data are provided by the World Glacier Monitoring Service (WGMS, 2012). Surveys of seasonal mass balance covering more than four decades are available for Glacier de Sarennes (Thibert and others, 2013) and Vernagtferner (Escher-Vetter and others, 2009).

Meteorological data are required for extrapolating point mass balances according to our approach (see below). We use daily mean air temperature and precipitation from several dozen MeteoSwiss weather stations in the vicinity of the investigated glaciers (Fig. 1), providing continuous records for the entire period of interest. For temperature, we mostly use homogenized series provided by Begert and others (2005); for precipitation, we rely on the station closest to the study site.

\section{METHODS}

Various approaches are currently used to calculate glacierwide mass balance from point measurements, ranging from the profile and contour line method (Østrem and Stanley, 1969; Kaser and others, 2003) to the application of kriging (Hock and Jensen, 1999). The extrapolation of mass balance to the entire glacier surface always involves uncertainties, 
depending on the number of measurements and on the spatial variability of mass balance (e.g. Cogley, 1999; Pelto, 2000). In this study, we rely on an alternative methodology, which combines the point observations with mass-balance modelling for interpolation and extrapolation to unmeasured areas. The principle of our approach is the constraining of a distributed model with all available field data in every individual year (Huss and others, 2009a). Modelling is thus used for spatial extrapolation of point mass balance; the seasonal/annual signal is given by the in situ measurements.

The applied approach has several important advantages over traditional methods. (1) Extrapolation in space is based on an algorithm that includes the main processes governing mass-balance distribution. This allows us to cope with a relatively small spatial density of surveyed points. (2) Data gaps, i.e. individual years with missing measurements, present for some of the series (Fig. 1; Table 1), can be filled in a consistent way. (3) Temporal differences between the hydrological year and the effective dates of the surveys can be corrected, enabling the joint evaluation of mass balance over the fixed-date system and the measurement period.

\section{Mass-balance model}

We use a distributed accumulation and temperature-index melt model, operating at a grid size of $25 \mathrm{~m}$ and daily resolution (Hock, 1999; Huss and others, 2008). Input data are (1) point mass balance over an arbitrary period of $\sim 1$ year, (2) winter snow accumulation (if available), (3) an up-to-date DEM and glacier outlines (Bauder and others, 2007) and (4) daily air temperature and precipitation.

Degree-day factors are varied as a function of potential direct solar radiation, in order to account for the effects of slope, aspect and shading. Daily surface melt rates, $M$, at day $t$ for gridcell $(x, y)$ are computed according to Hock (1999):

$$
M(x, y, t)= \begin{cases}\left(f_{\mathrm{M}}+r_{\text {snow } / \text { ice }} I_{\text {pot }}\right) T: & T>0^{\circ} \mathrm{C} \\ 0 & : \quad T \leq 0^{\circ} \mathrm{C},\end{cases}
$$

where $f_{\mathrm{M}}$ denotes a melt factor, $r_{\text {snow/ice }}$ are radiation factors for snow and ice surfaces and $I_{\text {pot }}=I_{\text {pot }}(x, y, t)$ is potential solar radiation. Air temperature, $T=T(x, y, t)$, is extrapolated to the median glacier elevation using monthly lapse rates derived from weather stations surrounding the study site, and is then distributed to every gridcell using a constant local lapse rate, $\mathrm{d} T / \mathrm{d} z$ (Huss and others, 2008).

Snow accumulation, $C$, is calculated based on measured precipitation, $P(t)$, occurring at $T$ lower than a threshold temperature of $1.5^{\circ} \mathrm{C}$ as

$$
C(x, y, t)=P(t) \cdot c_{\text {prec }} \cdot D_{\text {snow }}(x, y) \text {. }
$$

$C_{\text {prec }}$ allows the bias in precipitation between the weather station and the glacier to be corrected for. The variation in accumulation over the glacier is taken into account by using a dimensionless spatial multiplier, $D_{\text {snow }}(x, y)$, which is derived for each glacier individually by combining different factors influencing the snow accumulation distribution as follows. (1) $D_{\text {snow }}$ is first approximated by an altitudinal precipitation gradient, $\mathrm{d} P / \mathrm{d} z$. A second gradient can be prescribed to account for wind-driven reduction in accumulation at high elevation. (2) For years with a dense coverage of measurements, a spatial accumulation anomaly is computed from the in situ data according to Huss and others (2009a) and is superimposed on the results of (1). (3) In addition, small-scale accumulation variability is derived from terrain characteristics, following Huss and others (2008). $D_{\text {snow }}$ is normalized to an average of 1 over the glacier surface and is allowed to vary between 0 (no snow deposition) and $\sim 2$ (twice as much snow as average). Using the spatially adjusted factor, $D_{\text {snow, }}$ the description of the actual variation of mass-balance components over the glacier surface is substantially improved (not shown).

For all years with in situ observations the model is calibrated individually in a semi-automatic procedure. $C_{\text {prec }}$ (Eqn (2)) is constrained based on the direct winter accumulation measurements, if available. Melt parameters $f_{\mathrm{M}}, r_{\text {snow }}$ and $r_{\text {ice }}($ Eqn (1)) are tuned so that the root-mean-square error (RMSE) between modelled and observed annual point balance is minimized and the average misfit is zero. Whereas melt and accumulation parameters vary annually in order to match the field data, temperature and precipitation gradients, $\mathrm{d} T / \mathrm{d} z$ and $\mathrm{d} P / \mathrm{d} z$, are constant over time but are globally adjusted to maximize agreement with the seasonal field observations. For years without winter accumulation and/or annual mass-balance data, average parameters for periods with measurements from the same glacier are used.

We evaluate mass balances for both the measurement period and the fixed-date system (Cogley and others, 2011). All results shown in this paper refer to the measurement period defined by the exact dates of the surveys, usually in late September (annual balance) and in April/May (winter balance). We calculate conventional balance (Elsberg and others, 2001), i.e. mass balance is extrapolated to the actual glacier surface in the year of the measurements. Digital elevation models and outlines are available (Bauder and others, 2007) in intervals of a few years for most glaciers (Fig. 1). Ice surface elevation and extent is interpolated between the DEMs assuming linear changes, in order to obtain an annually updated glacier geometry (Huss and others, 2008). Accumulation-area ratio and ELA are evaluated from the final mass-balance distribution. For Clariden, the ablation process of frontal ice break-off was accounted for by estimating flow speed and thickness for a flux gate, and mass losses were added to surface melt. The contribution of this process was, however, smaller than the overall uncertainty in all years.

\section{Validation against geodetic mass change}

Glacier-wide mass balances calculated from the in situ measurements are validated against independent ice volume changes provided by repeated geodetic surveys (Fig. 3). Volume change is converted to mass change assuming a density of $850 \pm 60 \mathrm{~kg} \mathrm{~m}^{-3}$ for all glaciers (Huss, 2013).

A bias between glaciological and geodetic surveys can be explained by (1) internal and basal components not captured by surface mass-balance measurements, (2) erroneous extrapolation from the point measurements to the entire glacier and (3) uncertainties in both the direct field observations and geodetic mass changes (Thibert and others, 2008; Zemp and others, 2013). We assume (1) to be negligible for temperate alpine glaciers and consider the uncertainties in both methods to be randomly distributed, so errors over long periods are small. Error assessment indicated that the uncertainty in geodetic mass balance derived from photogrammetric DEMs is $\sim 0.05-0.15 \mathrm{mw}^{-e . \mathrm{a}^{-1}}$ (Zemp and others, 2013, provide a review of different studies). An average difference between glaciological and geodetic mass balance significantly larger than this value (Thibert and Vincent, 2009) is thus probably due to inaccurate interpolation 


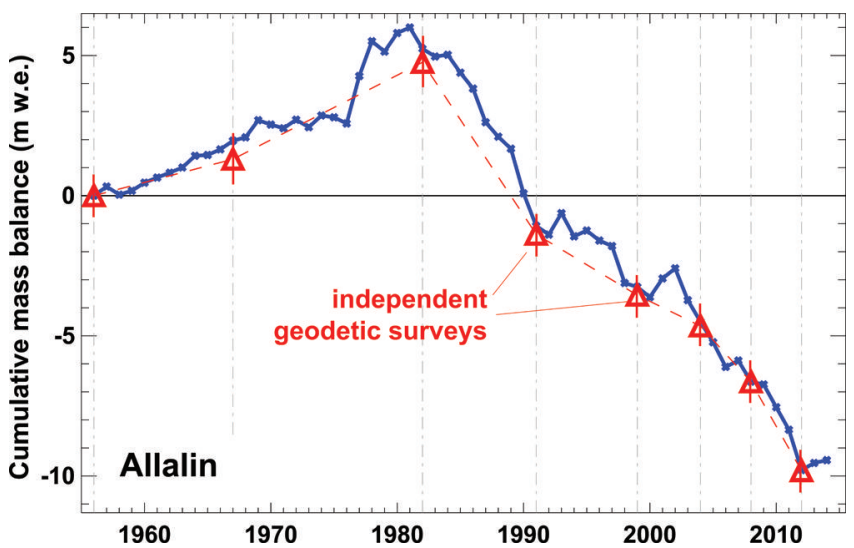

Fig. 3. Comparison of cumulative glaciological mass balance for Allalin with independent mass change from geodetic surveys (triangles).

and extrapolation of the point data and indicates a bias in computed glacier-wide annual balance.

If a difference $>0.1 \mathrm{~m}$ w.e. $\mathrm{a}^{-1}$ between glaciological and geodetic balance was detected for an individual period defined by two subsequent DEMs, the model was recalibrated to more realistically represent the mass balance in regions not covered by direct observations. We do not follow Huss and others (2009a) or Zemp and others (2013), who propose the final mass-balance distribution be adjusted to exactly match mass change given by the geodetic surveys. That approach might be problematic, due to the uncertainties inherent in geodetic balances. Instead, we aim to reach agreement between glaciological and geodetic balance by re-calibrating the parameters of our model used for extrapolation of the point data. As the melt and accumulation parameters (Eqns (1) and (2)) are directly constrained by the seasonal observations they are not suitable for this purpose. Model parameters defining spatial accumulation/ablation variability (e.g. $\mathrm{d} T / \mathrm{d} z, \mathrm{~d} P / \mathrm{d} z$ and $D_{\text {snow }}$ ) were thus iteratively varied, in order to reduce the bias in mass change but to preserve the match of calculated and observed mass balance at the location of point measurements.

The temporal and spatial variability of computed mass balance is thus given by the direct (seasonal) point measurements, whereas the long-term volume change, and hence the glacier-wide balance, is constrained by the geodetic surveys (similar to the approach of Letréguilly and Reynaud, 1989). This combination is expected to considerably reduce the uncertainties in evaluated glacierwide mass balance, and reasonable results are possible, even for glaciers with relatively few point measurements, or occasional data gaps.

Glaciological and geodetic mass balance agreed well for most glaciers and periods without rigorously adapting the parameters (Fig. 3). In some cases, however, more extensive recalibration was necessary to reconcile the two series. For Clariden and Aletsch (Fig. 2a and c), $D_{\text {snow }}$ (Eqn (2)) was spatially adjusted to account for effects of strong lateral precipitation gradients. For other sites (e.g. Allalin and Hohlaub (Fig. 2d)), accumulation at high elevation was overestimated assuming linear precipitation gradients. Accordingly, precipitation was reduced above $3500 \mathrm{ma.s.l}$. to achieve agreement with geodetic mass balance. We consider these adjustments to be stable over time, as they depend on sitespecific characteristics rather than annually varying effects.

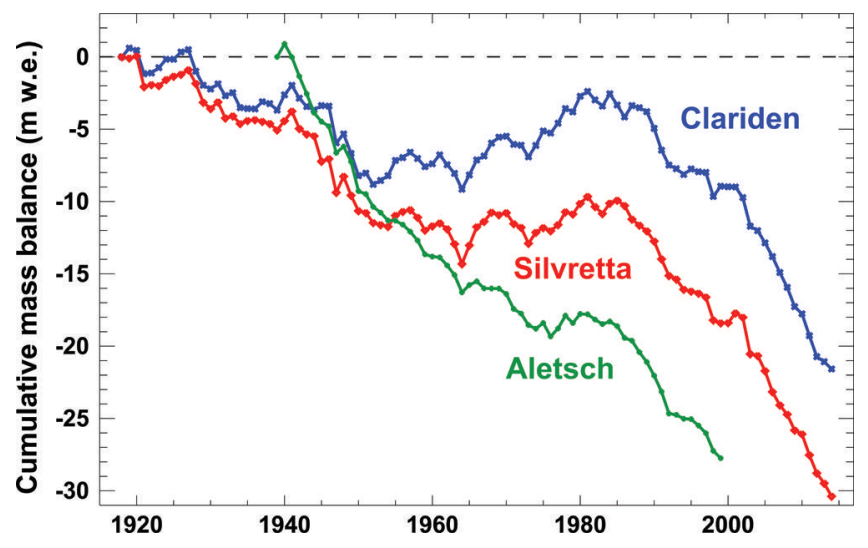

Fig. 4. Cumulative mass balance for Clariden and Silvretta (19182014) and Aletsch (1939-1999).

\section{RESULTS}

Area-averaged mass balance was computed for all investigated glaciers using the above methodology for the time interval with direct observations (Table 1). Measurements of winter accumulation are lacking over part of the study period for some series. For these years seasonal mass balance was again derived using the calibrated model and meteorological information, but results are flagged accordingly.

\section{Cumulative mass balance}

The series for Clariden and Silvretta are the first glacier-wide mass-balance records worldwide with a coverage of 100 years (Fig. 4). Mass balances were predominantly negative between 1920 and 1965, with accelerated mass loss in the 1940s. After a phase with moderate mass gains lasting until the late 1980 s, persistently negative balances have been observed until the present. Although Silvretta is subject to a slightly larger cumulative mass loss, the temporal variations are similar to Clariden. This is attributed to the climatological setting of both glaciers, north of the main Alpine divide (Fig. 1) and to their comparable altitudinal range (Table 1). The long-term series of Aletsch show a different pattern, with substantially more negative mass balances and smaller year-to-year variability (Fig. 4). Mass gain was only recorded during a short period in the late 1970s. We suggest the temporal mass-balance evolution of Aletsch is consistent with its large area and, hence, long volume response time (Jóhannesson and others, 1989).

All cumulative long-term mass-balance series evaluated in this study show mass loss since the mid-1980s, the rates being similar for most glaciers (Fig. 5). In the 1960s and 1970s, however, the differences are remarkable. Whereas some glaciers (Allalin, Clariden, Schwarzberg) gained mass - also manifested by intermittent advances of their termini other glaciers (Aletsch, Limmern) were subject to a reduction in ice volume.

Positive decadal mass balances occurred during the 1960s and 1970s. Before (since the 1920s) and afterwards only negative decadal mean balances are found (Table 2). Differences among the glaciers can be attributed to their geometry, i.e. how fast they adapt to changed climatic conditions by retreat of their terminus (e.g. Huss and others, 2012), and to variations in regional climate. Glaciers in the Mattmark region (Allalin, Schwarzberg, Hohlaub), for example, experienced strong mass gains in the 1970s 


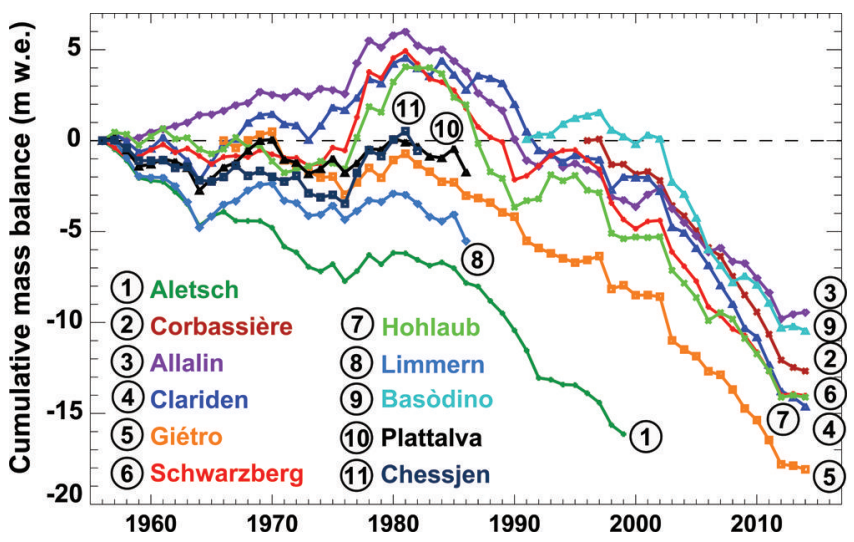

Fig. 5. Cumulative mass balance since 1955 for selected long-term series evaluated in this study. Glaciers are ordered according to their surface area. Note that series for Giétro, Basòdino and Corbassière start in 1966, 1991 and 1996, respectively.

(Fig. 5) which might be a regional effect due to particular meteorological conditions.

\section{Seasonal mass balance}

Glacier-wide seasonal series with a centennial scope clearly indicate that mass changes are driven by summer balance (Fig. 6; Vincent and others, 2004). Although some variations in winter balance are evident, low-pass filtered series do not show any consistent long-term pattern but strong interannual variability. Years with exceptionally negative annual balance over the last century were (in this sequence) 1947, 2003, 1921, 1998 and 1950. For the investigated glaciers, balances in the decade 2003-12 were most negative on average relative to the entire study period, with not a single positive mass-balance year (Fig. 6).

Variations of the three neighbouring glaciers Allalin, Schwarzberg and Hohlaub are similar (Fig. 7). Unlike other series, most negative balances occurred during the 1980s (Table 2). Slightly smaller rates of mass loss over the past two decades might be related to substantial retreat of their steep tongues, and their accumulation zones extending to $>4000$ ma.s.l. (Table 1). Glaciers influenced by the meteorological conditions south of the Alps showed an almost balanced mass budget in the hydrological years 2012/13 and 2013/14 (Fig. 7a-e).

Figure 8 presents additional shorter series of seasonal/ annual balance evaluated in this study. Although all these monitoring programmes have been discontinued, they provide valuable information on the temporal and spatial dynamics of mass-balance fluctuations in the Swiss Alps. The unique series of direct measurements at Rhone indicates significant mass loss during the end of the 19th and the beginning of the 20th century. Tsanfleuron fills in a gap in mass-balance data before 1950 for the western Alps and shows similar variations to Clariden and Silvretta (Fig. 6). The short series of Forno and Albigna represent Europe's first mass-balance observations south of the main Alpine divide, and provide evidence of a negative mass budget in the late 1950s for this region (Fig. 8). Detailed observations at Hohwäng (Schnyder, 2009) show extreme mass gains of up to $2 \mathrm{~m}$ w.e. $\mathrm{a}^{-1}$ in the late $1970 \mathrm{~s}$, confirming the results of nearby glaciers (Fig. $7 \mathrm{a}-\mathrm{c}$ ).

Throughout the European Alps only two series longer than four decades provide a seasonal resolution based on

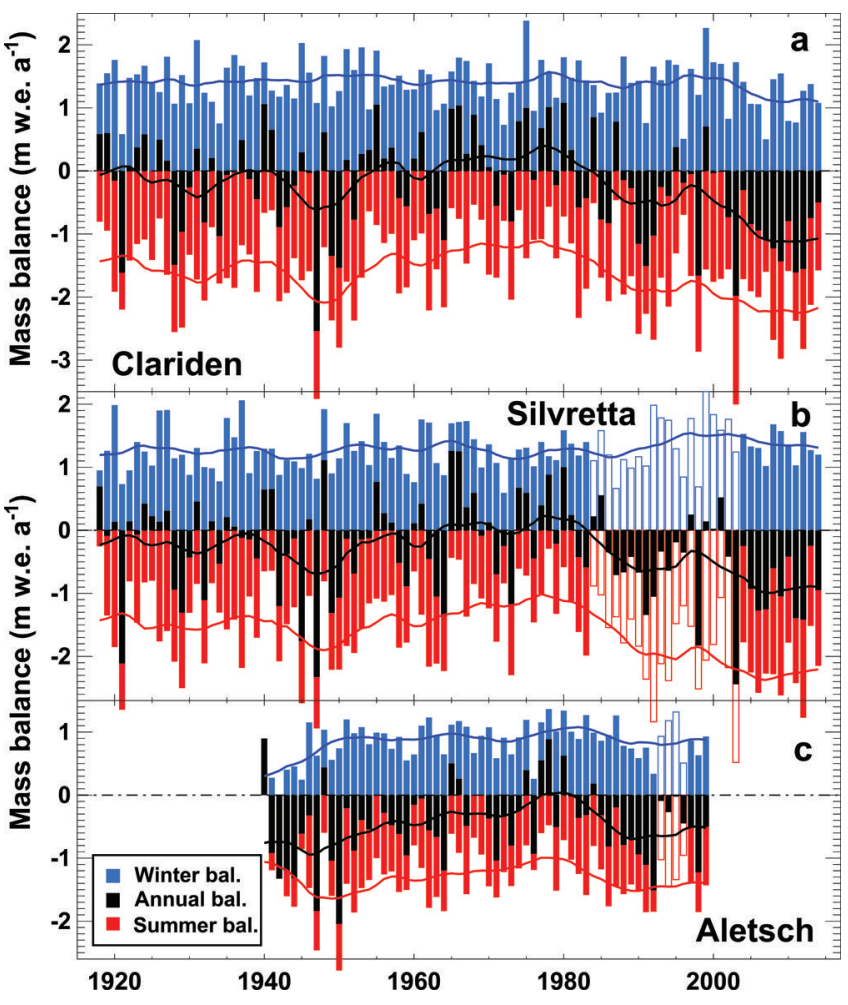

Fig. 6. Seasonal mass-balance series for (a) Clariden, (b) Silvretta and (c) Aletsch since 1918. Curves show 11 year running means for annual, winter and summer balance. For years with no direct observations of winter accumulation, seasonal balances are modelbased and bars are displayed with their outlines only.

continuous direct measurements (Sarennes, Vernagt). The present study adds six new seasonal long-term records (Table 1), allowing a more detailed assessment of the drivers of glacier mass change. In order to analyse variations in winter and summer balance, $B_{\mathrm{w}}$ and $B_{\mathrm{s}}$, the deviation of these components from the glacier-specific average over the period 1971-2010, common to all series, was evaluated (Table 3).

Decadal anomalies in winter balance relative to $1971-$ 2010 are small $\left(<0.20\right.$ mw.e. $\left.^{-1}\right)$ and do not show any stable pattern between the glaciers and the evaluated periods. They seem to be mostly driven by local meteorological conditions, as in the case of Allalin and Schwarzberg in the 1970s. $\Delta B_{\mathrm{w}}$ was negative, except for one glacier

Table 2. Decadal averages of annual mass balance (mw.e. $\mathrm{a}^{-1}$ ) between 1950 and 2010 for selected glaciers (series covering $>30$ years)

\begin{tabular}{|c|c|c|c|c|c|c|}
\hline Glacier & $\overline{B_{50 \mathrm{~s}}}$ & $\overline{B_{60 \mathrm{~s}}}$ & $\overline{B_{70 \mathrm{~s}}}$ & $\overline{B_{80 \mathrm{~s}}}$ & $\overline{B_{90 \mathrm{~s}}}$ & $\overline{B_{00 \mathrm{~s}}}$ \\
\hline Clariden & -0.11 & +0.19 & +0.28 & -0.22 & -0.40 & -0.88 \\
\hline Silvretta & -0.31 & -0.07 & +0.12 & -0.17 & -0.59 & -0.78 \\
\hline Aletsch & -0.55 & -0.26 & -0.14 & -0.43 & -0.63 & - \\
\hline Allalin & - & +0.21 & +0.33 & -0.57 & -0.37 & -0.39 \\
\hline Schwarzberg & - & -0.02 & +0.53 & -0.67 & -0.27 & -0.68 \\
\hline Hohlaub & - & -0.14 & +0.44 & -0.69 & -0.16 & -0.64 \\
\hline Giétro & - & - & -0.16 & -0.31 & -0.43 & -0.69 \\
\hline Limmern & -0.50 & -0.03 & -0.05 & - & - & - \\
\hline Plattalva & -0.32 & +0.14 & +0.01 & - & - & - \\
\hline Gries & - & -0.15 & -0.01 & -0.86 & -0.92 & -1.38 \\
\hline
\end{tabular}




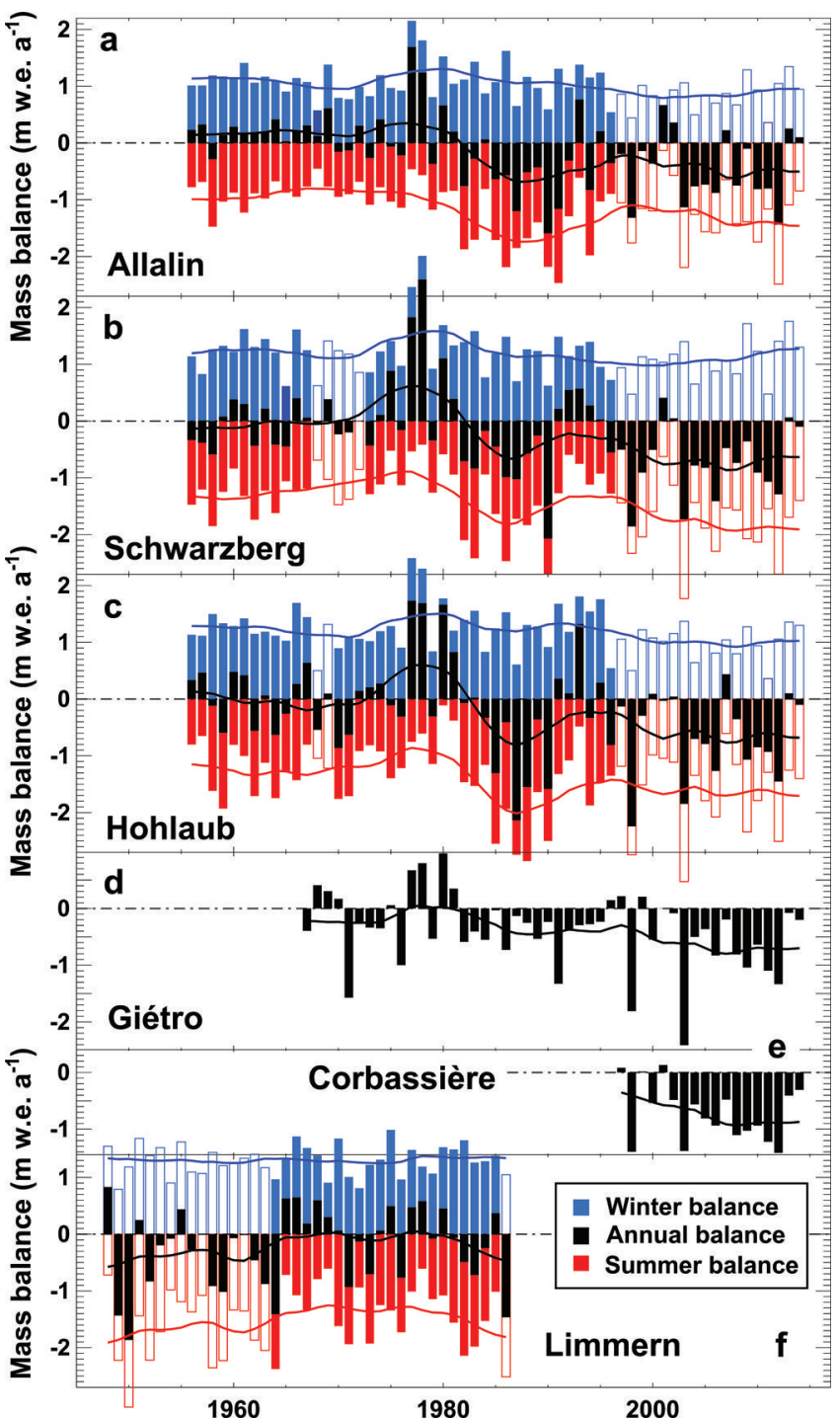

Fig. 7. Seasonal/annual mass-balance series for (a) Allalin, (b) Schwarzberg, (c) Hohlaub, (d) Giétro, (e) Corbassière and (f) Limmern since 1948. Curves show 11 year running means for annual, winter and summer balance. For years with no direct observations in winter, bars for seasonal balance are displayed with their outlines only. For Giétro and Corbassière no seasonal balances are available.

between 2000 and 2010, which might indicate an earlier onset of the melting season (Table 3). Anomalies in summer balance are more consistently distributed throughout the Alps. This agrees with previous studies (Letréguilly and Reynaud, 1989; Vincent, 2002; Vincent and others, 2004), and is in line with the sensitivity characteristics of alpine

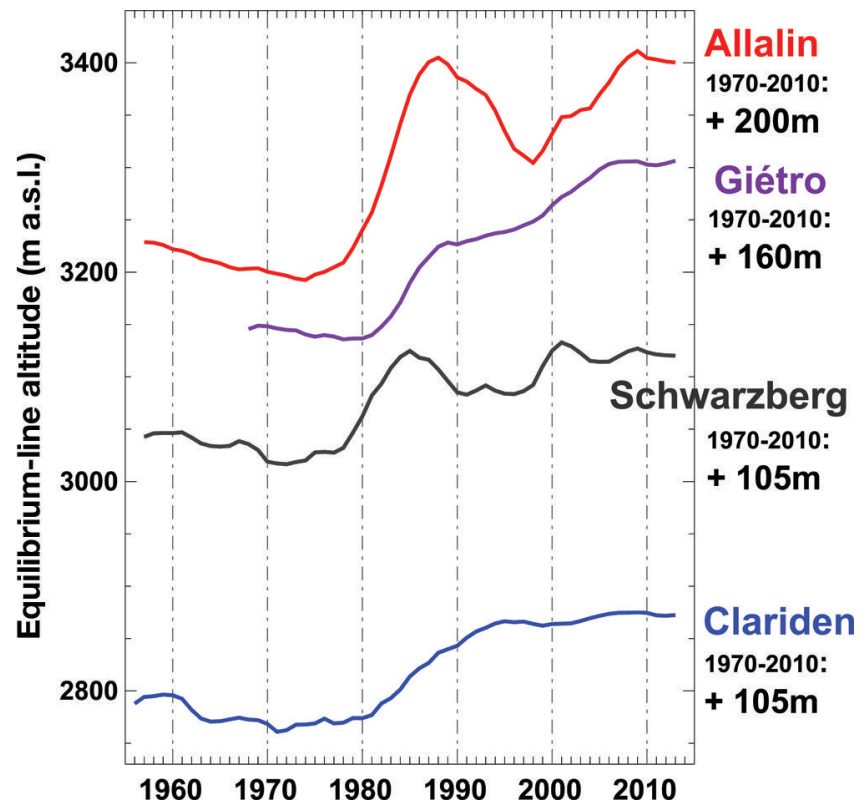

Fig. 9. Long-term change in ELA for selected glaciers. Time series are low-pass filtered with an 11 year running mean, and ELA change between 1970 and 2010 is given on the right. For all glaciers, ELA is below the highest point (see Table 1 for elevation ranges).

glaciers (Oerlemans and Reichert, 2000). Especially during phases of mass gain (1960s-70s) all glaciers showed strongly positive summer balance anomalies. For 2000-10, $\Delta B_{\mathrm{s}}$ is particularly negative for Sarennes, whereas the anomaly for Allalin is close to zero (Table 3 ). This divergence might be attributed to the influence of dynamic glacier response on area-averaged mass balance contributing to less summer melting for Allalin, due to retreat to higher elevation, and to increased ablation for Sarennes because of complete loss of the accumulation area, downwasting and, hence, enhanced radiative forcing.

\section{Changes in ELA}

The evaluated mass-balance series allow an assessment of the changes in ELA over the last few decades (Fig. 9). Whereas the balanced-budget ELA was at $\sim 2780 \mathrm{~m}$ a.s.I. on average for Clariden in the 1960 s, it was at $3200 \mathrm{~m}$ a.s.I. for Allalin. This is related to differences in solid precipitation, radiation and air temperature between the sites (e.g. Ohmura and others, 1992). The ELA of Schwarzberg is $\sim 200 \mathrm{~m}$ lower than that of Allalin, although these glaciers are just a few kilometres apart and both are exposed to the northeast (Fig. 2d). However, Schwarzberg is closer to the main weather divide and receives higher amounts of winter accumulation (Fig. 7).

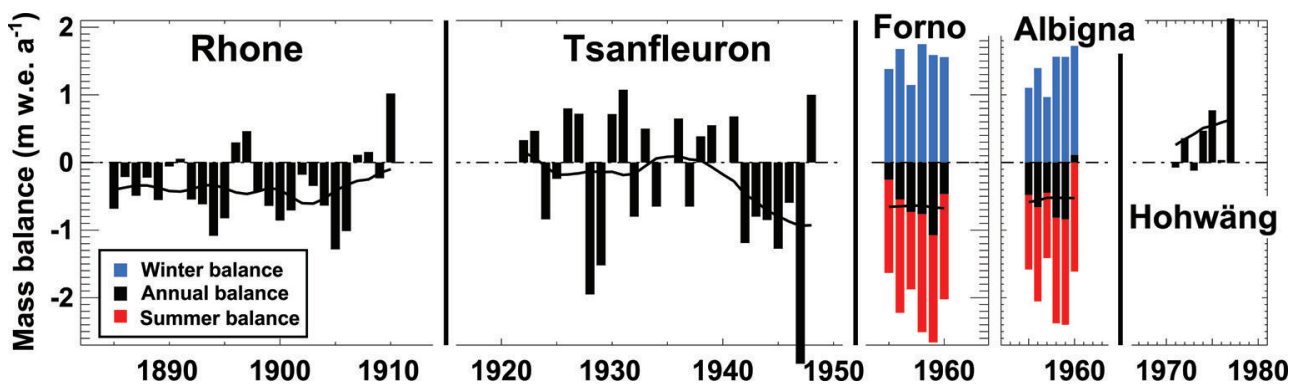

Fig. 8. Seasonal/annual series for Rhone, Tsanfleuron, Forno, Albigna and Hohwäng shown on a single time axis. 
Changes in ELA are often considered a good proxy for assessing the imbalance of a glacier and to infer corresponding changes in the mass budget (Kuhn, 1989; Benn, 2000). Based on our results we evaluate the mass-balance sensitivity in response to the observed ELA shift between 1970 and 2010. Sensitivities are $-0.3 \mathrm{~m}$ w.e. $\mathrm{a}^{-1}$ per $100 \mathrm{~m}$ ELA rise for Allalin, Hohlaub and Giétro, $-0.7 \mathrm{~m}$ w.e. $\mathrm{a}^{-1}$ per $100 \mathrm{~m}$ for Silvretta and Schwarzberg, and $-1.3 \mathrm{~m}$ w.e. $\mathrm{a}^{-1}$ per $100 \mathrm{~m}$ for Clariden. The considerable differences in observed sensitivity to ELA change are higher than those found by Six and Vincent (2014) in a similar study. Our results indicate that estimating the change in glacier-wide balance from shifts in ELA over multi-decadal periods is not straightforward (e.g. Rabatel and others, 2008). We suggest that the strong variations in sensitivity are (1) related to the dynamic adjustment of glacier geometry over time and the corresponding effect on area-averaged mass balance, and due to differences in (2) glacier hypsometry and (3) accumulation distribution. For Clariden the ELA is presently located in a region with high snow accumulation, where important changes in melting result in a relatively small shift in ELA.

\section{DISCUSSION}

\section{European mass-balance variability}

The new mass-balance series for Switzerland strengthen the sample of glacier monitoring data and increase our understanding of mass-balance variability throughout the European Alps during the past century. Between 1950 and 1990 the series evaluated in the frame of this study comprise 40$50 \%$ of all mass-balance records in the Alps (WGMS, 2012), almost doubling the coverage of long-term observations.

In order to investigate mass-balance changes in different regions, all records $>20$ years were arithmetically averaged over decadal periods for Switzerland, Austria, Italy and France (Fig. 10). For each country between one and six series since 1960 were available (WGMS, 2012). Six additional long-term records are provided by this study. During the 1960s and 1970s, mass balances in all regions of the Alps were in a relatively narrow range. In the 1980s and onwards, the mean mass balance of Italian glaciers was substantially more negative $\left(\sim 0.5 \mathrm{~m}\right.$ w.e. $\left.\mathrm{a}^{-1}\right)$ than that of the Swiss and Austrian glaciers. In the first decade of the $21 \mathrm{st}$ century the mass balance of French glaciers showed a drastic drop to values of almost -2 mw.e. $\mathrm{a}^{-1}$, which persisted into the most recent years (Fig. 10). For Switzerland, the new series agree well with the published records, with a tendency towards slightly smaller mass loss.

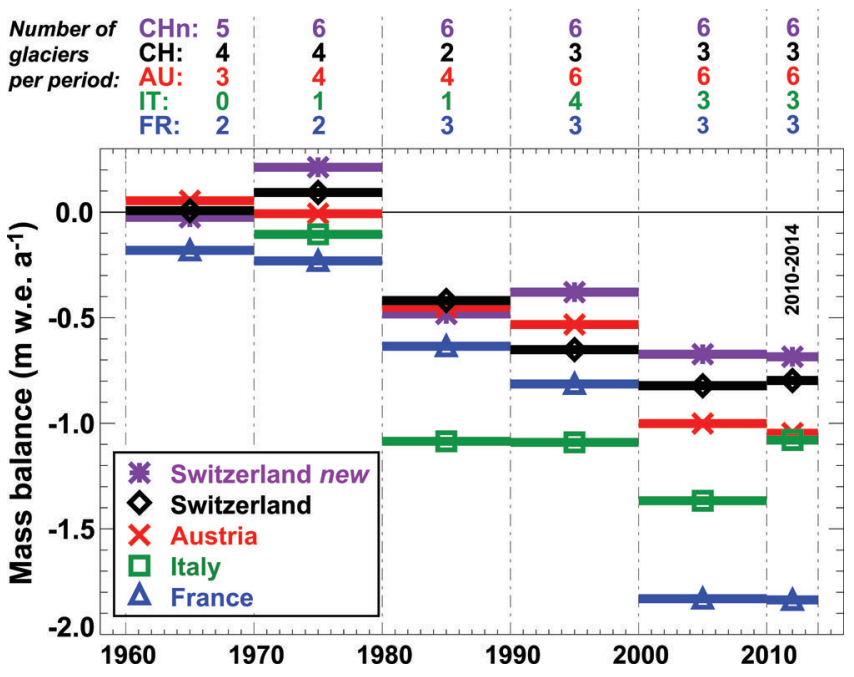

Fig. 10. Decadal mean mass balance for Switzerland, Austria, Italy and France obtained by arithmetically averaging all series $>20$ years from WGMS (2012) as well as the new records for Switzerland (this study). The number of available series per period is given.

Although mass-balance records in different regions of the Alps show the same temporal trends, the spread between the south/west and the north/east significantly increases over time, indicating a loss in regional consistency (Fig. 10). This may be explained by a climate shift towards more adverse conditions for the French and Italian glaciers, or by their higher sensitivity to changes in forcing. Considering the signal of individual series, however, indicates that the reference glaciers, Sarennes (France) and Careser (Italy), might be partly responsible for the very negative regional balances in comparison with the other Alpine countries. Signs of disintegration have recently been documented for both glaciers (Carturan and others, 2013; Thibert and others, 2013). Sarennes and Careser have lost their accumulation zones; the downwasting in the ablation area leads to a lowering of surface albedo and increased longwave heat input from exposed rock surrounding the ice.

In the context of the European Alps, the series compiled in this study refer to rather large glaciers. Many of them are located in areas with important ice coverage and extend up to the highest peaks (Table 1). In comparison to small glaciers in peripheral regions, they are expected to be in a healthier state, being able to dynamically respond (e.g. by a retreat to higher elevations) to a change in forcing. Hence, they react in a more representative way regarding the mass change of the entire mountain range, which is dominated by the larger glaciers. The less-negative mass balance of the

Table 3. Long-term series with seasonal resolution in the European Alps. The deviation of winter balance, $\Delta B_{\mathrm{w}}$ (mw.e.), and summer balance, $\Delta B_{\mathrm{s}}$ (m w.e.), from the average over 1971-2010 for the respective glacier is given in decadal periods since the 1950s

\begin{tabular}{|c|c|c|c|c|c|c|c|c|c|c|c|c|}
\hline \multirow[t]{2}{*}{ Glacier } & \multicolumn{2}{|c|}{ 1950-60 } & \multicolumn{2}{|c|}{ 1960-70 } & \multicolumn{2}{|c|}{ 1970-80 } & \multicolumn{2}{|c|}{ 1980-90 } & \multicolumn{2}{|c|}{ 1990-2000 } & \multicolumn{2}{|c|}{ 2000-10 } \\
\hline & $\Delta B_{\mathrm{w}}$ & $\Delta B_{\mathrm{s}}$ & $\Delta B_{\mathrm{w}}$ & $\Delta B_{\mathrm{s}}$ & $\Delta B_{\mathrm{w}}$ & $\Delta B_{\mathrm{s}}$ & $\Delta B_{\mathrm{w}}$ & $\Delta B_{\mathrm{s}}$ & $\Delta B_{\mathrm{w}}$ & $\Delta B_{\mathrm{s}}$ & $\Delta B_{\mathrm{w}}$ & $\Delta B_{\mathrm{s}}$ \\
\hline Clariden & +0.14 & +0.26 & +0.09 & +0.42 & +0.04 & +0.56 & +0.03 & +0.07 & +0.09 & -0.17 & -0.17 & -0.45 \\
\hline Silvretta & -0.04 & +0.31 & +0.11 & +0.38 & -0.16 & +0.62 & -0.15 & +0.25 & +0.19 & -0.34 & +0.11 & -0.54 \\
\hline Allalin & - & - & +0.04 & +0.42 & +0.18 & +0.40 & +0.03 & -0.35 & -0.05 & -0.07 & -0.16 & +0.02 \\
\hline Schwarzberg & - & - & +0.04 & +0.21 & +0.25 & +0.55 & -0.03 & -0.36 & -0.13 & +0.13 & -0.09 & -0.32 \\
\hline Sarennes & -0.20 & +0.57 & -0.18 & +1.01 & -0.21 & +0.96 & +0.24 & -0.03 & +0.11 & +0.15 & -0.14 & -1.08 \\
\hline Vernagt & - & - & - & - & -0.06 & +0.55 & +0.11 & -0.07 & +0.01 & -0.19 & -0.06 & -0.29 \\
\hline
\end{tabular}


new series over the past few decades relative to all other Alpine regions (Fig. 10) supports this conclusion and suggests that future long-term monitoring efforts should focus on medium-to-large glaciers. In even the near future, mass-balance glaciers might disintegrate and disappear and we should now begin alternative measurements on glaciers with a larger elevation range.

\section{Uncertainties}

Estimating the uncertainty in the seasonal mass-balance records provided in this study is difficult and depends on numerous factors. In general, there are two levels of uncertainty: (1) long-term average balances (e.g. decadal means), which are expected to be relatively accurate as they are partly constrained by observed ice volume changes, and (2) annual and seasonal mass balances, which are likely to be somewhat more uncertain. Year-to-year variability in our series, as well as the seasonal components, are directly given by the field measurements. The results are thus prone to various uncertainties related to the acquisition and evaluation of in situ mass-balance data.

Interpolation and extrapolation of point annual mass balance to the glacier surface was performed, ensuring that cumulative mass change from the glaciological method agreed with geodetic balance within the uncertainties of the latter (Fig. 3). We therefore consider the uncertainty in average mass balances over longer time spans to be given by that of the geodetic method, i.e. $\sigma_{(1)}= \pm 0.05-0.15 \mathrm{~m} \mathrm{w.e.}^{-1}$ (e.g. Zemp and others, 2013). The accuracy of inferred longterm means of annual mass balance is expected to be higher with increasing length of the time interval considered. In order to increase the long-term accuracy of mass-balance series, future efforts should focus on a more detailed assessment of the uncertainties in the geodetic average balances and the reasons for potential differences with glaciological balances.

The uncertainty in evaluated glacier-wide annual mass balance depends on (1) the accuracy of point accumulation/ ablation measurements, (2) their spatial density and distribution over the glacier surface, (3) their local representativeness, (4) the extrapolation into unmeasured regions (model-based in our case), (5) the accuracy of glacier area and surface geometry over which mass balance is evaluated, (6) the availability of information on the measurement dates and (7) the occurrence of data gaps in the series. Individually quantifying all these components for all series and years is beyond the scope of this paper. Based on previous studies (Thibert and others, 2008; Huss and others, 2009a; Zemp and others, 2013) and simple considerations, we estimate approximate uncertainties for each of the above factors and combine them to find randomly distributed errors in annual mass balance of $\sigma_{(2)}= \pm 0.15-0.40 \mathrm{mw}$ e. $\mathrm{a}^{-1}$. Due to combination with geodetic surveys we assume that component (4), often regarded as the most important source of uncertainty in mass-balance studies (e.g. Zemp and others, 2013), is relatively small. For glaciers with a dense network of measurement sites we assume the uncertainty to be close to the lower bound of our estimate. For series with data gaps and/or a limited number of annual measurements (Table 1), we expect higher uncertainties.

The uncertainty in inferred seasonal mass-balance components is likely to be of the same order as for annual balance, or even higher. Regular monitoring of the complex distribution of snow accumulation was not performed for any of the glaciers and winter balance was mostly derived from only a few measurements (Table 1). Furthermore, the geodetic surveys do not contain any information on seasonal mass balance and are thus not helpful in constraining the spatial pattern of winter accumulation in unsampled regions.

\section{Measurement point density}

For some series the spatial point density is relatively small (Table 1). The question arises whether the mass-balance signal can be adequately captured with such a dataset. The reader is referred to studies that have investigated the minimal point density for mass-balance determination in detail (Cogley, 1999; Fountain and Vecchia, 1999; Pelto, 2000). In general, the number of required point measurements depends on glacier size, mass-balance variability and the methodology applied to derive glacier-wide balance.

In order to assess the relevance of limited spatial point density to our methodology, we performed a sensitivity test for Giétro and Limmern. For each year we randomly selected $20 \%(50 \%)$ of all measurements and recalculated mass balance for the entire period based on the reduced dataset. Results were compared with the annual series derived using all available data. We found a RMSE of $0.28 \mathrm{~m}$ w.e. $\mathrm{a}^{-1}$ if $20 \%$ of the measurements were used and $0.17 \mathrm{~m}$ w.e. $\mathrm{a}^{-1}$ if $50 \%$ were included for the mass-balance calculation. The values are in agreement with our uncertainty estimate for annual mass balance. The long-term cumulative mass balance remains unaffected, as our approach ensures consistency with geodetic mass changes. The differences compared with the reference dataset indicate that our methodology is relatively insensitive to spatial point density and the relevant mass-balance signal is still revealed if only a few measurements are available in individual years. This is attributed to (1) the application of modelling for spatial extrapolation and (2) the use of geodetic balances for constraining the series.

Combining measurements and modelling for mass-balance determination is beneficial in different aspects, as demonstrated in this study. However, we must be aware that a certain fuzziness might be introduced in some cases. Our approach allows consistent reconstruction of mass balance for individual years with missing data, based on calibrated model parameters. For these years, the signal is given by meteorological information only and might differ from the actual conditions on the glacier. This is illustrated for Allalin, Schwarzberg and Hohlaub, for which winter balance measurements were discontinued in the 1990s (Fig. 7). Whereas seasonal mass-balance components showed differences between the glaciers before 1996, the variations are in phase afterwards, as the same weather station has been used for all sites. If at least one in situ measurement point per year is available, the inferred mass-balance signal can be considered to be independent of the meteorological series.

\section{CONCLUSION}

We have presented a comprehensive collection of massbalance data for Swiss glaciers throughout the 20th century. Nineteen new or re-analysed series of glacier-wide seasonal balance have been derived, based on in situ observations compiled from previously unpublished and unevaluated data. Six of the new series are $>50$ years and two cover 100 years. These two records are the longest continuous 
glacier-wide mass-balance series worldwide, and provide the first direct observations of seasonal/annual mass change before 1946. The combination of glaciological mass balance with periodic ice volume changes based on photogrammetry allows us to greatly reduce the uncertainties when inferring area-averaged balance. Our multidecadal seasonal series are unique in their temporal and spatial coverage and are expected to offer an extended basis for studying glacier response to climate change throughout almost the entire instrumental period.

Analysis of the new mass-balance records in connection with published series for the European Alps confirmed that long-term variations in summer balance have a high consistency over large distances, whereas the variability in winter balance shows remarkable regional differences. Our results provide information on glacier mass balance for the most strongly glacierized region of the Alps - with relatively large glaciers at high elevation - which was previously not covered by direct glaciological measurements. Comparison with other long-term records (often referring to rather small and low-lying glaciers in the periphery of the main Alpine crest) indicates that mountain-range mass balance calculated from these series might be biased towards too-negative values. This might be explained by a lack of representativeness by peripheral and/or low-lying glaciers of the mass balance of the entire Alpine region, and a shift in the processes governing glacier sensitivity to climate change during the past few decades.

The added value of a careful and complete compilation and re-analysis of historical and unpublished mass-balance data has been demonstrated. The rescuing of scattered field measurements acquired over the last century is highly important to prevent them from being lost to the glaciological community. This direct long-term information allows us to considerably increase our process understanding regarding the glacier/climate relation and to enhance models for projecting future glacier change.

\section{ACKNOWLEDGEMENTS}

This study would not have been possible without countless Swiss scientists measuring glacier mass balance in the field for many years and decades, often only because of their personal interest in glaciology. To mention just a few, we are grateful for the contributions by M. Aellen, H. Bösch, M. Funk, G. Kappenberger, P. Kasser, A. Lemans, H. Müller, H. Röthlisberger, B. Schnyder, H. Siegenthaler and U. Steinegger. Kraftwerke Mattmark AG and Forces Motrices de Mauvoisin SA provided long-term support for some of the series. The WGMS is acknowledged for collecting and distributing mass-balance data. MeteoSwiss supplied the weather data. M. Funk and M. Hoelzle commented on an earlier version of the manuscript. Suggestions by two anonymous reviewers were helpful in finalizing the paper.

\section{REFERENCES}

Aellen M (1996) Glacier mass balance studies in the Swiss Alps. Z. Gletscherkd. Glazialgeol., 31, 159-168

Aellen M and Funk M (1990) Bilan hydrologique du bassin versant de la Massa et bilan de masse des glaciers d'Aletsch (Alpes bernoises, Suisse). IAHS Publ. 193 (Symposium at Lausanne Hydrology in Mountain Regions), 89-98
Bauder A, Funk M and Huss M (2007) Ice volume changes of selected glaciers in the Swiss Alps since the end of the 19th century. Ann. Glaciol., 46, 145-149 (doi: 10.3189/172756407782871701)

Begert M, Schlegel T and Kirchhofer W (2005) Homogeneous temperature and precipitation series of Switzerland from 1864 to 2000. Int. J. Climatol., 25(1), 65-80 (doi: 10.1002/joc.1118)

Benn D (2000) Mass balance and equilibrium-line altitudes of glaciers in high-mountain environments. Quat. Int., 65, 15-29 (doi: 10.1016/S1040-6182(99)00034-8)

Braithwaite RJ (2002) Glacier mass balance: the first 50 years of international monitoring. Progr. Phys. Geogr., 26(1), 76-95 (doi: 10.1191/0309133302pp326ra)

Braithwaite RJ (2009) After six decades of monitoring glacier mass balance we still need data but it should be richer data. Ann. Glaciol., 50(50), 191-197 (doi: 10.3189/172756409787769573)

Carturan L and 11 others (2013) Decay of a long-term monitored glacier: the Careser glacier (Ortles-Cevedale, European Alps). Cryosphere, 7, 1819-1838 (doi: 10.5194/tc-7-1819-2013)

Cogley JG (1999) Effective sample size for glacier mass balance. Geogr. Ann. A, 81(4), 497-507 (doi: 10.1111/1468-0459.00079)

Cogley JG (2009) Geodetic and direct mass balance measurements: comparison and joint analysis. Ann. Glaciol., 50(50), 96-100 (doi: 10.3189/172756409787769744)

Cogley JG and 10 others (2011) Glossary of glacier mass balance and related terms. (IHP-VII Technical Documents in Hydrology No. 86, IACS Contribution No. 2) UNESCO - International Hydrological Programme

Dyurgerov MB and Meier MF (1999) Analysis of winter and summer glacier mass balances. Geogr. Ann. A, 81(4), 541-554 (doi: 10.1111/1468-0459.00082)

Elsberg DH, Harrison WD, Echelmeyer KA and Krimmel RM (2001) Quantifying the effects of climate and surface change on glacier mass balance. J. Glaciol., 47(159), 649-658 (doi: 10.3189/ 172756501781831783)

Escher-Vetter H, Kuhn M and Weber M (2009) Four decades of winter mass balance of Vernagtferner and Hintereisferner, Austria: methodology and results. Ann. Glaciol., 50, 87-95 (doi: 10.3189/172756409787769672)

Firnberichte (1914-78) Der Firnzuwachs 1913/14-1976/77 in einigen schweizerischen Firngebieten. Vierteljahresschr. Naturforsch. Ges. Zürich, 1-64

Fischer A (2011) Comparison of direct and geodetic mass balances on a multi-annual time scale. Cryosphere, 5, 107-124 (10.5194/ tc-5-107-2011)

Fountain, AG and Vecchia A (1999) How many stakes are required to measure the mass balance of a glacier? 81(4), 563-573 (doi: 10.1111/1468-0459.00084)

Gardner AS and 15 others (2013) A reconciled estimate of glacier contributions to sea level rise: 2003 to 2009. Science, 340(6134), 852-857 (doi: 10.1126/science.1234532)

Glaciological reports (1881-2014) The Swiss Glaciers, 1880-2008/ 09, Yearbooks of the Cryospheric Commission of the Swiss Academy of Sciences (SCNAT), 1-130. Published since 1964 by VAW-ETH Zürich

Haeberli W, Hoelzle M, Paul F and Zemp M (2007) Integrated monitoring of mountain glaciers as key indicators of global climate change: the European Alps. Ann. Glaciol., 46, 150-160 (doi: 10.3189/172756407782871512)

Harrison WD, Elsberg DH, Cox LH and March RS (2005) Correspondence. Different mass balances for climatic and hydrologic applications. J. Glaciol., 51(172), 176

Hock R (1999) A distributed temperature-index ice- and snowmelt model including potential direct solar radiation. J. Glaciol., 45(149), 101-111

Hock R and Jensen H (1999) Application of kriging interpolation for glacier mass balance computations. Geogr. Ann. A, 81(4), 611-619 (doi: 10.1111/1468-0459.00089)

Hock R, Funk M and Müller-Lemans H (1993) Analyse langjähriger Schneemessungen auf dem Limmerngletscher, Glarner Alpen. Zürcher Geogr. Schr. 53 
Huss M (2012) Extrapolating glacier mass balance to the mountainrange scale: the European Alps 1900-2100. Cryosphere, 6, 713-727 (doi: 10.5194/tc-6-713-2012)

Huss M (2013) Density assumptions for converting geodetic glacier volume change to mass change. Cryosphere, 7, 877-887 (doi: 10.5194/tc-7-877-2013)

Huss M and Bauder A (2009) 20th-century climate change inferred from four long-term point observations of seasonal mass balance. Ann. Glaciol., 50(50), 207-214 (doi: 10.3189/ 172756409787769645)

Huss M, Bauder A, Funk M and Hock R (2008) Determination of the seasonal mass balance of four Alpine glaciers since 1865 . J. Geophys. Res., 113(F1), F01015 (doi: 10.1029/2007JF000803)

Huss M, Bauder A and Funk M (2009a) Homogenization of longterm mass-balance time series. Ann. Glaciol., 50(50), 198-206 (doi: 10.3189/172756409787769627)

Huss M, Funk M and Ohmura A (2009b) Strong Alpine glacier melt in the 1940s due to enhanced solar radiation. Geophys. Res. Lett., 36(23), L23501 (doi: 10.1029/2009GL040789)

Huss M, Hock R, Bauder A and Funk M (2012) Conventional versus reference-surface mass balance. J. Glaciol., 58(208), 278-286 (doi: 10.3189/2012JoG11J216)

Jóhannesson, T, Raymond C and Waddington E (1989) Time-scale for adjustment of glaciers to changes in mass balance. J. Glaciol., 35(121), 355-369

Kaser G, Fountain A and Jansson P (2003) A manual for monitoring the mass balance of mountain glaciers. (IHP-VI Technical Documents in Hydrology No. 59) UNESCO - Intenational Hydrology Programme

Kaser G, Cogley JG, Dyurgerov MB, Meier MF and Ohmura A (2006) Mass balance of glaciers and ice caps: consensus estimates for 1961-2004. Geophys. Res. Lett., 33(19), L19501 (doi: 10.1029/2006GL027511)

Kuhn M (1989) The response of the equilibrium line altitude to climate fluctuations: theory and observations. In Glacier fluctuations and climatic change. (Glaciology and Quaternary Geology 6) Springer, Berlin, 407-417

Kuhn M, Markel G, Kaser G, Nickus U, Obleitner F and Schneider H (1985) Fluctuations of climate and mass balances: different responses of two adjacent glaciers. Z. Gletscherkd. Glazialgeol., 21(1), 409-416

Letréguilly A and Reynaud L (1989) Spatial patterns of massbalance fluctuations of North American glaciers. J. Glaciol., 35(120), 163-168

Mercanton PL (1916) Vermessungen am Rhonegletscher/Mensurations au Glacier du Rhone, 1874-1915. Neue Denkschr. Schweiz. Naturforsch. Ges., 52

Müller H and Kappenberger G (1991) Claridenfirn-Messungen 1914-1984. Zürcher Geogr. Schr., 40

Oerlemans J and Fortuin JPF (1992) Sensitivity of glaciers and small ice caps to greenhouse warming. Science, 258(5079), 115-117 (doi: 10.1126/science.258.5079.115)

Oerlemans J and Reichert BK (2000) Relating glacier mass balance to meteorological data by using a seasonal sensitivity characteristic. J. Glaciol., 46(152), 1-6

Ohmura A, Kasser P and Funk M (1992) Climate at the equilibrium line of glaciers. J. Glaciol., 38(130), 397-411
Ohmura A, Bauder A, Müller H and Kappenberger G (2007) Long-term change of mass balance and the role of radiation. Ann. Glaciol., 46(152), 367-374 (doi: 10.3189/ 172756500781833269)

Østrem G and Stanley A eds (1969) Glacier mass-balance measurements:- a manual for field and office work. Department of Energy, Mines and Resources, Ottawa, Ont.; Norwegian Water Resources and Electricity Board, Oslo

Pelto MS (2000) The impact of sampling density on glacier mass balance determination. Hydrol. Process., 14, 3215-3225

Rabatel A, Dedieu J-P, Thibert E, Letréguilly A and Vincent C (2008) 25 years (1981-2005) of equilibrium-line altitude and massbalance reconstruction on Glacier Blanc, French Alps, using remote-sensing methods and meteorological data. J. Glaciol., 54(185), 307-314 (doi: 10.3189/002214308784886063)

Radić V and Hock R (2014) Glaciers in the Earth's hydrological cycle: assessments of glacier mass and runoff changes on global and regional scales. Surv. Geophys., 35, 813-837 (doi: 10.1007/s10712-013-9262-y)

Schnyder B (2009) Massenbilanz Hohwänggletscher - Ergebnisse der Haushaltsjahre 1970/71-1976/77. Zmtt-Zermatt

Six D and Vincent C (2014) Sensitivity of mass balance and equilibrium-line altitude to climate change in the French Alps. J. Glaciol., 60(223), 867-878

Thibert E and Vincent C (2009) Best possible estimation of mass balance combining glaciological and geodetic methods. Ann. Glaciol., 50, 112-118 (doi: 10.3189/172756409787769546)

Thibert E, Blanc R, Vincent C and Eckert N (2008) Glaciological and volumetric mass balance measurements error analysis over 51 years for the Sarennes glacier, French Alps. J. Glaciol., 54(186), 522-532 (doi: 10.3189/002214308785837093)

Thibert E, Eckert N and Vincent C (2013) Climatic drivers of seasonal glacier mass balances: an analysis of 6 decades at Glacier de Sarennes (French Alps). Cryosphere, 7, 47-66 (doi: 10.5194/tc-7-47-2013)

Vincent C (2002) Influence of climate change over the 20th century on four French glacier mass balances. J. Geophys. Res., 107(D19), 4375 (doi: 10.1029/2001JD000832)

Vincent C, Kappenberger G, Valla F, Bauder A, Funk M and Le Meur E (2004) Ice ablation as evidence of climate change in the Alps over the 20th century. J. Geophys. Res., 109(D10), D10104 (doi: 10.1029/2003JD003857)

World Glacier Monitoring Services (WGMS) (2012) Fluctuations of glaciers, 2005-2010 (Vol. X) ed. Zemp M and 7 others. ICSU (WDS)/IUGG(IACS)/UNEP/UNESCO/WMO, World Glacier Monitoring Service, Zürich (doi: 10.5904/wgms-fog-2012-11)

Zemp M, Hoelzle M and Haeberli W (2009) Six decades of glacier mass-balance observations: a review of the worldwide monitoring network. Ann. Glaciol., 50(50), 101-111 (doi: 10.3189/ $172756409787769591)$

Zemp M and 6 others (2010) Reanalysis of multi-temporal aerial images of Storglaciären, Sweden (1959-99) - Part 2: Comparison of glaciological and volumetric mass balances. Cryosphere, 4, 345-357 (doi: 10.5194/tc-4-345-2010)

Zemp M and 16 others (2013) Reanalysing glacier mass balance measurement series. Cryosphere, 7, 1227-1245 (doi: 10.5194/ tc-7-1227-2013) 